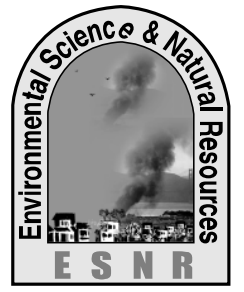

J. Environ. Sci. \& Natural Resources, 5(2): 11 - 14, 2013

ISSN 1999-7361

\title{
Status of Heavy Metal Contaminations of Drain Water of Dhaka Metropolitan City
}

\author{
M. A. A. Mokaddes, B. S. Nahar ${ }^{1}$ and M. A. Baten \\ Department of Environmental Science, ${ }^{1}$ Center for Environmental Studies \\ Bangladesh Agricultural University, Mymensingh
}

\begin{abstract}
A study was conducted to evaluate the status of heavy metal contaminations of drainage water of Dhaka Metropolitan City. The water samples were collected from four major drains of Dhaka metropolitan city during February to March, 2008. The chemical analysis of water samples ( $\mathrm{pH}, \mathrm{EC}, \mathrm{As}, \mathrm{Cu}, \mathrm{Mn}$, 'ln. $\mathrm{Pb}$ and $\mathrm{Cd}$ ) was conducted at the Central Laboratory of Bangladesh Agricultural University, Mymensingh. The chemical concentrations of drain water were: in case of $\mathrm{pH}=5.13$, in case of $\mathrm{EC}=$ $33.36\left(\mu \mathrm{scm}^{-1}\right)$, in case of $\mathrm{Cu}=0.129 \mathrm{ppm}$, in case of $\mathrm{Zn}=1.276 \mathrm{ppm}$, in case of $\mathrm{Mn}=0.109 \mathrm{ppm}$, in case of As $=0.036 \mathrm{ppb}$, in case of $=\mathrm{Pb} 0.004 \mathrm{ppm}$, and in case of $\mathrm{Cd}=0.228 \mathrm{ppm}$. The average $\mathrm{pH}$ value of drain water ranged from 4.96 to 5.34 and the mean was 5.138, which was an indicating of strong acidic in nature. The mean EC value of drainage water was recorded 33.363 $\mu \mathrm{Scm}^{-1}$, all the water samples indicated low to medium salinity. According to drinking water (Potable water) and public water standard, Mn, and Cd toxicity were detected in drain water. According to WHO for aquaculture standard Mn and Cd were harmful level for all living organism. Some water were found unsuitable due to higher concentration of Mn over the recommended limit but other ions like $\mathrm{Zn}, \mathrm{As}$, and $\mathrm{Pb}$ were within the safe limit.
\end{abstract}

Kew Words: Heavy metals, Drains, Dhaka City

\section{Introduction}

Bangladesh is one of the most density populated country of the world with population growth rate of 1.48 per annum (BBS, 2005). Dhaka, the capital city of Bangladesh is expanding enormously day by day.

Dhaka Metropolitan city carries polluted drains, lakes and rivers. Though water is an inevitable component of natural resources and plays an important role to serve as many purposes like drinking, irrigation, aquaculture and livestock usage, the people of Dhaka city are polluting it adding different types of pollutants to its adjacent drains. Water quality is deteriorated day by day due to many of biological, physical and chemical variables causing water toxicity. Water is acting as a solvent and various types of heavy metals are dissolved in its, but the concentration of any element or compound beyond tolerance limit for organisms and other usage, treated as pollutants. Water is the most abundant resource in Bangladesh (Azad, 2003), we need to take care of it.

In Bangladesh, water sources are being polluted due to poor sanitation facilities. The average sanitation coverage in Bangladesh is around $43 \%$ which indicates that rest $57 \%$ of the 150 million people lack sanitation facilities (Ali, 2002a). Everyday 20,000 metric tons of faeces deposited in the open places of Dhaka city due to open defecation and hanging latrines pollute the water bodies like river, cannels, drains and ponds etc. (Ali, 2002b). Tannery and other industrial wastes, unplanned sewage system, medical wastes, nuclear and toxic materials polluting waters as well as the environment, threatening people's liver with health hazards related to toxicity (Abadeen, 2002).

The Hajariabag tanari drain, Santibag, drain, Malibag drain, Lalbag area outlet drains Sutrapur drain, Gulsan drain, Uttara drains are attractive drains is now highly polluted with different chemical residues released from different industries. There are plenty of industries that the spontaneously polluting our drains. About 3072 industrial polluting entities are polluting the Hajariabag tanari drain, Santibag, drain, Malibag drain, Lalbag and the tanneries of Hajaribag is the major sources (Anonymous, 1997).

The quality of water is judged by its total salt concentration, relative proportion of cations and anions, the concentration of toxic substances. But the toxicity varied from season to season. In most cases, macro and micro nutrients were higher in winter season than those during the monsoon season (Mitra and Gupta, 1999). If low quality water is used for irrigation, drinking, domestic, industrial and other purposes, ionic toxicity may appear (Zaman and Rahman, 1996).

In the study area the surface water are used for irrigation (for home, kitchen gardening and field crop irrigation), drinking and domestic uses, airconditioning, beverage, confectionary, laundering, dyeing, ice factory, cold storage, brick field and other industries. In view of the above mentioned multidirectional usage, a study have been conducted to assess the water quality from different non-point 
sources of the Hajariabag tanari drain , Santibag, drain, Malibag drain, Lalbag area outlet drains Sutrapur drain, Gulsan drain, Uttara drains etc.

The present study was conducted with the following objectives:

i) To determine the heavy metals present in the water environment drainages water of Dhaka metropolitan city and their degree of toxicity; and

ii) To identify the suitability of freshwater for irrigation, aquaculture and livestock usage on the basis of international standard.

\section{Materials and Methods}

Water samples were collected from four drains of Dhaka Metropolitan City during February to March 2008. The water samples were collected in $100 \mathrm{ml}$ plastic bottles. These bottles were cleaned with dilute $\mathrm{HCl}$ (1:1) and then washed with tap water and distilled water as well. Before sampling bottles were rinsed again 3 to 4 times with water to be sampled. After collection the bottles containing samples were sealed immediately to avoid exposure to air. The samples were taken from the midstream and few centimeters below th3e surface. To provide necessary information for each sample such as data collection, location, source of water, depth etc. were recorded in a note book and each sample collected in a plastic bottle, was labeled separately with unique identification number. After collecting, all samples were filtered with Whiteman No. 1 filter paper to remove unwanted solid and suspended materials before analysis. Then transferred $90 \mathrm{ml}$ of water sample into another $100 \mathrm{ml}$ bottle which contained $10 \mathrm{ml} 2 \mathrm{M} \mathrm{HCl}$ solution. $\mathrm{HCl}$ solution was protected water samples from any fungal and other pathogenic attack. After collection all the water samples were carried to the "Central Laboratory" of Bangladesh Agricultural University, Mymensingh for chemical analysis.

Heavy metals viz. $\mathrm{Cu}, \mathrm{Zn}, \mathrm{Mn}, \mathrm{Pd}, \mathrm{Cd}$ and As were determined with the help of atomic absorption spectrophotometer (AAS, UNICAM 969) following the method of Clesceri et al. (1989). The wavelengths of $\mathrm{Cu}, \mathrm{Mn}, \mathrm{Zn}, \mathrm{As}, \mathrm{Pb}$ and $\mathrm{Cd}$ were $324.8 \mathrm{~nm}, 213.9$ $\mathrm{nm}, 193.7 \mathrm{~nm}, 217.0 \mathrm{~nm}$, and $228.8 \mathrm{~nm}$, respectively.
Statistical Analysis of the data generated out of chemical analysis of water samples were done with help of Laptop following standard procedure (analysis of variance) as described by Gomez and Gomez (1984).

\section{Results}

The copper $(\mathrm{Cu})$ values of drain water in four locations, viz. Hajaribag Tanari $\left(\mathrm{S}_{42}\right)$, Santibag $\left(\mathrm{S}_{43}\right)$, Malibag $\left(\mathrm{S}_{44}\right)$ and Lalbag area outlet $\left(\mathrm{S}_{45}\right)$ were 0.121 ppm, $0.131 \mathrm{ppm}, 0.128 \mathrm{ppm}$ and $0.135 \mathrm{ppm}$. The mean value, standard deviation and co-efficient of variation were $0.129,0.006$ and $4.59 \%$, respectively. Two samples (50\%) showed below the mean (8.68) and other Two samples $(50 \%)$ were above. Drain water contained higher amount of $\mathrm{Cu}$ than that of river and lake water (Table 1).

The zinc ( $\mathrm{Zn}$ ) values of drain water in four locations Hajaribag Tanari $\left(\mathrm{S}_{42}\right)$, Santibag $\left(\mathrm{S}_{43}\right)$, Malibag $\left(\mathrm{S}_{44}\right)$, and Lalbag area outlet $\left(\mathrm{S}_{45}\right)$ were $1.255 \mathrm{ppm}, 1.265$ ppm, $1.29 \mathrm{ppm}$ and $1.295 \mathrm{ppm}$, respectively. The mean value, standard deviation and co-efficient of variation were $1.276,0.019$ and $1.513 \%$, respectively. Two samples (50\%) showed below the mean (1.276) and other two samples (50\%) were above (Table 1).

The manganese $(\mathrm{Mn})$ values of drain water in four locations Hajaribag Tanari $\left(\mathrm{S}_{42}\right)$, Santibag $\left(\mathrm{S}_{43}\right)$, Malibag $\left(\mathrm{S}_{44}\right)$ and Lalbag area outlet $\left(\mathrm{S}_{45}\right)$ were $0.1089 \mathrm{ppm}, 0.1091 \mathrm{ppm}, 0.1095 \mathrm{ppm}$ and 0.1099 ppm, respectively. The mean value, standard deviation and co-efficient of variation were 0.109 , 0.00 and $0.406 \%$, respectively. One samples $(25 \%)$ showed below the mean value (0.109) and other two samples $(75 \%)$ were above. Among river, lake and drain highest amount of Mn was found in drain water (Table 1).

The arsenic (As) values of drian water in four locations Hajaribag Tanari $\left(\mathrm{S}_{42}\right)$, Santibag $\left(\mathrm{S}_{43}\right)$, Malibag $\left(\mathrm{S}_{44}\right)$, and Lalbag outlet drain $\left(\mathrm{S}_{45}\right)$ were 0.03 ppb, $0.035 \mathrm{ppb}, 0.039 \mathrm{ppb}$ and $0.041 \mathrm{ppb}$, respectively. The mean value, standard deviation and co-efficient of variation were $0.036,0.005$ and $13.39 \%$, respectively. Two samples $(50 \%)$ showed below the mean value $(0.036 \mathrm{ppb})$ and other two samples (50\%) were above the mean value (Table 1). 
Table 01. Heavy metal ( $\mathrm{Cu}, \mathrm{Zn}, \mathrm{Mn}, \mathrm{Pd}, \mathrm{Cd}$ and As) concentrations of different drains in Dhaka city

\begin{tabular}{|c|l|c|c|c|c|c|c|c|}
\hline Sample & Name of drain & Location & $\mathrm{Cu}(\mathrm{ppm})$ & $\mathrm{Zn}(\mathrm{ppm})$ & $\mathrm{Mn}(\mathrm{ppm})$ & $\mathrm{As}(\mathrm{ppb})$ & $\mathrm{Pb}(\mathrm{ppm})$ & $\mathrm{Cd}(\mathrm{ppm})$ \\
\hline $\mathrm{S}_{42}$ & Hajaribag tanari drain & Hajaribag & 0.121 & 1.255 & 0.108 & 0.03 & 0.004 & 0.223 \\
\hline $\mathrm{S}_{43}$ & Santibag, drain & Santiba8 & 0.131 & 1.265 & 0.1091 & 0.035 & 0.0041 & 0.227 \\
\hline $\mathrm{S}_{44}$ & Malibag drain & Malibag & 0.128 & 1.29 & 0.1095 & 0.039 & 40043 & 0.229 \\
\hline $\mathrm{S}_{45}$ & Lalbag area outlet drain & Lalbag & 0.135 & 1.295 & 0.1099 & 0.041 & 0,0044 & 0.231 \\
\hline Mean & & & 0.129 & 1.276 & 0.109 & 0.036 & 0.004 & 0.228 \\
\hline $\mathrm{SD}$ & & & 0.006 & 0.019 & 0.000 & 0.005 & 0.000 & 0.003 \\
\hline $\mathrm{CV}$ & & & 4.590 & 1.513 & 0.406 & 13.397 & 4.347 & $\mathrm{I} .501$ \\
\hline
\end{tabular}

The $\mathrm{Pb}$ values of drain water in four locations Hajaribag Tanari $\left(\mathrm{S}_{42}\right)$, Santibag $\left(\mathrm{S}_{43}\right)$, Malibag $\left(\mathrm{S}_{44}\right)$ and Lalbag area outlet $\left(\mathrm{S}_{45}\right)$ were $0.004 \mathrm{ppm}, 0.0041$ ppm, $0.0043 \mathrm{ppm}$ and $0.0044 \mathrm{ppm}$. The mean value, standard deviation and co-efficient of variation were o.004, 0.00 and $4.37 \%$, respectively (Table 1). Two samples $(50 \%)$ showed below the mean (0.004) and other two samples (50\%) were above.

The $\mathrm{Cd}$ values of drain water in four locations Hajaribag Tanari $\left(\mathrm{S}_{42}\right)$, Santibag $\left(\mathrm{S}_{43}\right)$, Malibag $\left(\mathrm{S}_{44}\right)$, and Lalbag area outlet $\left(\mathrm{S}_{45}\right)$ were $0.223 \mathrm{ppm}, 0.227$ ppm, $0.229 \mathrm{ppm}$ and $0.231 \mathrm{ppm}$. The mean value, standard deviation and co-efficient of variation were $0.228,0.003$ and $1.501 \%$, respectively (Table 11 ). Two samples $(50 \%)$ showed below the mean $(0.228)$ and other two samples $(50 \%)$ were above.

\section{Discussion}

The present study was conducted to assess the heavy metal concentration and the degree of toxicity of different water sources drain in Dhaka metropolitan city. Water samples were collected randomly from four drains.

Surface water samples collected from the Dhaka metropolitan city area were categorized by analyzing chemical constituents. Several components like pH, $\mathrm{EC}, \mathrm{As}, \mathrm{Cu}, \mathrm{Mn}, \mathrm{Zn}, \mathrm{Pb}$ and $\mathrm{Cd}$ etc. were considered for the classification of different usage. The average $\mathrm{pH}$ value of drain water range from 4.96 to 5.34 which indicated strong acidic in nature. The average EC value for drains water ranged was $33.363 \mu \mathrm{Scm}^{-1}$ where EC value varied from water were 33.25 to $33.47 \mu_{\mathrm{Scm}^{-1}}$ for drains water and all the water samples indicate low to medium salinity. Again the EC of surface water also excellent for irrigation in acid loving crops and unsuitable for drinking purpose and home use.

From the experiment, the As concentrations of drain water were same and ranged from 0.03 to $0.041 \mathrm{ppm}$, which is under the recommended limit of drinking, irrigation and livestock consumption.

The average value of $\mathrm{Cu}$ was $0.129 \mathrm{ppm}$, According to WHO (1972) and U.S. Environmental Protection Agency (1975) the water of study areas were harmful for drinking.

The concentration of Manganese (Mn) for drains water was 0.109 ppm which was unsuitable for drinking and irrigation.

Recommendation concentration of Mn for drinking is $0.05 \mathrm{mgL}^{-1}$ (U.S Environmental Protection Agency, 1975) as shown Appendix III. According to the recommendation to the above mentioned agency all the tested water samples were unsuitable for drinking.

Lead $(\mathrm{Pb})$ status varied from 0.004 to $0.0044 \mathrm{ppm}$ for drains water and the average concentration of $\mathrm{Pb}$ was 0.004 ppm.

The concentration of Zinc $(\mathrm{Zn})$ in drain water varied from 1.255 to $1.290 \mathrm{ppm}$. In case of $\mathrm{Zn}$ concentration the samples of surface water was unsuitable for drinking and irrigation water all the samples were lower than the maximum permissible limit.

\section{Conclusion}

It may be concluded from the study that the lakes of Dhaka metropolitan city contained acceptable amount of $\mathrm{As}, \mathrm{Zn}, \mathrm{Pb}, \mathrm{Cd}$; where $\mathrm{Mn}$ exceeded the recommended limit for drinking water, irrigation water and for aquaculture. In that sense $\mathrm{Mn}$ is hazardous for health, crops and aquaculture. All the water of drains of Dhaka city can not safely be used for specific purpose after without proper treatment. Routine research work with wide public awareness, government participation and government regulations can save the water of Dhaka metropolitan city and thus a safe and sound water environment can be made for future generations. 


\section{References}

Abadeen, M. J. 2002. Industrial waster. Give earth a chance. World Environment Day, 5 June 2002. Report Dept. Env., The Government of Bangladesh.

Ali, A. M. 2002a. Public Private Partnership for Controlling Air Pollution: The case of Dhaka Urban Transport Project, Bangladesh.

Ali, M. A. 2002b. Public private priority for water resource management in Bangladesh water. Two billion people are dying for it! World Environment Days 5 June 2003. Dept. Env. The Government of Bangladesh.

Anonymous, 1997. Industrial pollution a public health hazard (editorial column). The Bangladesh observer, September 6, p. 7.

Azad, A. K. 2003. Impacts of Farakka barrage on surface water resources in Bangladesh. World Environment Day 5 June 2003. Report, Dept. Env., The Government of Bangladesh. Pp. 40-43.

BBS. 2005. Statistical year book of Bangladesh published by Bangladesh Bureau of Statistics.
Clesceri, L. S.; Greenberg, A. E. and Trussel, R. R. 1989. Standard Method for the Examination of Water and Waste Water. $17^{\text {th }}$ edn., American Public Health Asso., Washington D. C. 20005. pp. 1-30, 40-175.

Davis, S. N. and De Wiest, R. J. M. 1966. Hydrology, John Wiley and Sons, Inc. New York. 263p.

Gomez, K. A. and Gomez, A. A. 1984. Statistical Proceedure for Agricultural Research. $2^{\text {nd }}$ edn. Rice Res. Inst., Book. A Wiley Inter Science Publication, New York. P. 28.

Mitra, A. and Gupta, S. K. 1999. Effect of sewage water irrigation on essential plant nutrient and pollutant element status in vegetable growing area aroundx Calcutta. J. India Soc. Soil Sci., 47(1): 99-105.

WHO (World Health Organization). 1972. International standards for drinking water. Cited from ground water assessment development and management. Pp. 248-249.

Zaman, M.W. and Rahman, M.M. 1996. Ionic toxicity of Industrial process waters in some selected sites of Sirajgonj in Bangladesh. $J$. Environ.. Sci., 2:27-34. 